\title{
LORD DENNING AND MODERN ADMINISTRATIVE LAW
}

\author{
Christopher Forsyth ${ }^{*}$
}

\section{INTRODUCTION}

A life of one hundred years packed with unprecedented influence on the development of English law cannot be summed up in a conference of one day or one paper of a few pages. Even restricting that influence to administrative law leaves a task far too great to accomplish in this paper.' Indeed, a major part of this paper could be taken up simply by listing the areas in which judgments by Lord Denning remain vital to a proper understanding of administrative law. ${ }^{2}$

Thus I have decided on a different approach. I have selected four areas of importance in which either through developments since Lord Denning's retirement or otherwise the extent of his influence may be measured. ${ }^{3}$ Fortunately, there is only a little overlap between the areas which I have chosen and those chosen by Professor Dawn Oliver in her article elsewhere in this volume. ${ }^{4}$ The paper will then end with some more general remarks about Lord Denning's role in the development of administrative law including how it has been seen by others.

The areas which I have chosen in order to reveal the extent of his influence are the following. First of all, we may consider the development of the prerogative remedies starting with his "rediscovery" of certiorari for error of law on the face of the record. Since, as we shall see, most errors of

\footnotetext{
${ }^{*}$ Robinson College, Cambridge; Assistant Director of the Centre for Public Law, University of Cambridge.

${ }^{1}$ I take comfort from the fact that an excellent review of Lord Denning's influence in the area of administrative law already exists in the form of Jeffrey Jowell's essay, "Administrative Law" in Lord Denning: The Judge and the Law (Sweet \& Maxwell, 1984, ed. J.L. Jowell and J.P.W.B. McAuslan). There is also a less sympathetic account by Eric Young entitled "Development of a System of Administrative Law?' in Justice - Lord Denning and the Constitution (Gower, 1981, ed. P. Robson and P. Watchman) which will be discussed below.

${ }^{2}$ Jowell and McAuslan, supra $n .1$ at p. $\mathrm{x}$ reveal that there are more than 2,000 reported cases in which Lord Denning gave judgment.

${ }^{3}$ Others might well choose different areas but I do not believe that different conclusions would be reached.

4 "Lord Denning and The Public/Private Divide" p.71 infra.
} 
law made by public authorities take the authorities outside their jurisdiction, "error of law on the face of the record" is no longer of great importance in controlling the activities of such bodies. But this too comes about as a result of Lord Denning's work as will be explained below. Secondly, we will look at Lord Denning's contribution to the law of standing. As we shall see while Lord Denning has had his rebuffs in this area the logic of his basic position - that the rule of law requires that no decision should be beyond proper challenge and thus, where there is no other proper challenger, standing will be extended to any ordinary citizen has very largely been accepted. Thirdly, we will consider the protection of legitimate expectations which forms such a prominent part of the modern law of natural justice. We will see that not only was Lord Denning responsible largely alone for the introduction of this concept into English law but his ideas remain vital to mark the limits of this doctrine in modern law. Fourthly, and finally, we look at the juristic basis for the judicial review of non-statutory bodies. We shall see that Lord Denning's ideas have an important role to play in the development of this important facet of judicial review.

\section{ERROR OF LAW ON THE FACE OF THE RECORD AND JURISDICTIONAL ERRORS OF LAW}

May I commence with a very well worn quotation? In the first series of Hamlyn Lectures given by Lord Denning and published in Freedom under the Law he said:

"Our procedure for securing our personal freedom is efficient, but our procedure for preventing abuse of power is not. Just as the pick and shovel is no longer suitable for the winning of coal, so also the procedure of mandamus, certiorari, and actions on the case are no longer suitable for the winning of freedom in the new age. They must be replaced by new and up to date machinery, by declarations, injunctions and actions for negligence..."

The challenge of these words has undoubtedly been met as the system of administrative remedies we have today shows. ${ }^{6}$ And Lord Denning has, inevitably, played a major part in meeting that challenge. But the developments since Freedom under the Law are replete with at least two curious ironies which is why this seems to be an area worth looking at. First of all, it was Lord Denning himself who showed that there was life in the prerogative remedies yet. This was in $R$. v. Northumberland

\footnotetext{
5 (Stevens \& Co., 1949) at p.126.

${ }^{6}$ Lord Denning, The Discipline of Law (Butterworths, 1979) at pp. 61-62.
} 
Compensation Appeal Tribunal ex parte. Shaw. ${ }^{7}$ This was the case where the Tribunal had made an error in determining the compensation due in law to Shaw, a clerk who had been made redundant on the setting up of the National Health Service. No other error had been made and the old adage that "[i]f the tribunal had power to decide rightly, it had power to decide wrongly" seemed to stand in the way of a correction. Lord Denning disinterred the concept of "error of law on the face of the record" in reliance upon 17 th and 18 th century cases; ${ }^{8}$ and applied it to ensure that the correct compensation was paid. This concept of "error of law on the face of the record" played an useful part in the development of judicial review for some two decades. It provided a means where a legal erroneous decision could be set right even where no error had been made taking the decision-maker outside his jurisdiction.

However, in another ironic development it was then Lord Denning who rendered the jurisdiction to quash for error of law on the face of the record largely redundant by holding, in Pearlman v.Governors of Harrow School, that:

\begin{abstract}
"the distinction between an error which entails absence of jurisdiction and an error made within jurisdiction is very fine. So fine indeed that it is rapidly being eroded....So fine is the distinction that in truth the High Court has a choice whether to interfere with an inferior court on a point of law...I would suggest that this distinction should now be discarded. The High Court has, and should have, jurisdiction to control the proceedings of inferior courts and tribunals by way of judicial review. When they go wrong in law, the High Court should have the power to set them right. Not only in the instant case to do justice to the complainant. But also to secure that all courts and tribunals, when faced with the same point of law, should decide it in the same way.",
\end{abstract}

Now although Lord Denning may have been wrong in extending this principle to all inferior courts without qualification, his view has been accepted as the orthodox position in English administrative law. ${ }^{10}$

7 [1952] 1 K.B. 338.

${ }^{8}$ Groenwelt v. Burwell (1700-)1 Salk. 144; I Ld. Raym. 454-469 and R. v. Glamorganshire Inhabitants (1699)1 Salk. 146; 1 Ld. Raym. 580.

${ }^{9}$ [1978] 3 W.L.R. 736 at 744.

${ }^{10} R$. v. Hull University Visitor ex parte Page [1993] A.C. 682 and Re Racal Communications Ltd. [1981] A.C. 374. It should be pointed out that Lord Denning was not alone in collapsing the distinction between errors of law within jurisdiction and without jurisdiction. Lord Diplock being simply the most prominent of the other leading judges behind this development. 


\section{DENNING LAW JOURNAL}

Thus we see a consistent search for the extension of judicial review for the sound reasons of policy given in the quotation above. Although it is extended by rendering the jurisdiction to quash for error of law on the face of the law redundant, it is done so on a principled basis.

\section{STANDING AND THE VINDICATION OF THE RULE OF LAW}

The tale of Lord Denning's contribution to the law of standing in the public law is well known and told elsewhere. ${ }^{11}$ But it is an excellent tale worthy of brief repetition. Lord Denning's contribution in this area in linked to that of Raymond Blackburn, that extraordinary litigator who in person, although he had no particular interest in the matters in question, sought to prevent illegalities by public authorities. Blackburn had the good fortune to encounter Lord Denning on the bench to hear his cases. ${ }^{12}$ They were two of a pair. Lord Denning certainly approved of Mr. Blackburn and Mr. Blackburn thought Lord Denning was "the greatest living Englishman." 13 There were in fact four reported Blackburn cases. ${ }^{14}$ Although Mr. Blackburn was technically the loser in three of the cases, his intervention brought about a beneficial change of policy by the Commissioner of the Metropolitan Police in two of those three cases. Thus only one was a complete defeat: that in which he sought to prevent the U.K. from signing the Treaty of Rome! In none of these cases did Mr. Blackburn clearly satisfy the criteria for standing for the remedy which was sought. But the "greatest living litigator in person" and the "greatest living Englishman" worked it out.

The nub of Lord Denning's reasoning on the issue of standing in such

\footnotetext{
11 Wade \& Forsyth, Administrative Law (Oxford University Press, 7th ed. 1994) at pp.704 \& 711-8.

${ }^{12}$ Or perhaps more than good fortune, since Lord Denning was Master of the Rolls at the time.

${ }^{13}$ The Times, 7 th March, 1980. But Lord Denning mindful of recent defeats retorted: "Tell that to the House of Lords."

${ }^{14}$ Blackburn v. The Attorney-General [1971] 1 W.L.R. 1037 (declaration sought that H.M.G.
} had no right to sign Treaty of Rome; denied as treaty making non-justiciable but Lord Denning said "I would not myself rule him out on the ground that he has no standing."); $R$. v.

Commissioner of Police of the Metropolis ex parte Blackburn [1968] 2 Q.B. 118 (mandamus sought to require Commissioner to enforce the law on gaming; relief refused because Commissioner abandoned challenged policy on enforcement, applicant's standing left open); $R$. v. Commissioner of Police of the Metropolis ex parte Blackburn [1973] Q.B. 241 (mandamus sought to require Commissioner to enforce the law on obscene publications; relief refused because Commissioner increased number of officers in Obscene Publications Squad) and $R$. $v$. Greater London Council ex parte Blackburn [1976] 1 W.L.R. 550 (prohibition sought to prevent G.L.C. from using test of "obscenity" rather than "gross indecency" as required by law in licensing film; prohibition granted; as a ratepayer the applicant (Mrs. Blackburn) had sufficient standing). 
cases is to be found in the following dictum from the 1976 Blackburn case:

"I regard it as a matter of high constitutional principle that if there is a good ground for supposing that a government department or public authority is transgressing the law, or is about to transgress it, in a way which offends or injures thousands of Her Majesty's subjects, then any one of those offended or injured can draw it to the attention of the court of law and seek to have the law enforced, and the courts in their discretion can grant whatever remedy is appropriate. $" 15$

These words though must be considered in the light of one of Lord Denning's greatest defeats: Gouriet v. Union of Post Office Workers. ${ }^{16}$ Here it will be recalled that the House of Lords overruled Lord Denning's finding in the Court of Appeal that the Attorney-General was not the "final arbiter as to whether the [criminal] law should be enforced or not." Thus where the Attorney refused leave to an individual (without any special interest) to seek an injunction to prevent a breach of the criminal law, Lord Denning (joined by Lawton and Ormrod L.JJ.) held "any citizen in the land can come to the courts and ask that the law should be enforced." Although the 1976 Blackburn case was concerned with the standing required for prerogative relief and the Gouriet case was concerned with standing for an injunction, the logic of Lord Denning's position is the same. The rule of law is recognised as a fundamental constitutional principle, to which, if necessary, other principles give way. Thus standing must be extended to "any citizen in the land" if otherwise a decision would be unchallengeable.

Now while the Attorney-General seemingly remains beyond challenge, ${ }^{17}$ Lord Denning's logic has triumphed. Even Lord Diplock - his restraint minded "rival" if that is not too crass a way of putting it - concluded in what is still the leading case on the requirement of "sufficient interest" to bring an application for judicial review, $R$. v. Inland Revenue Commissioners ex parte National Federation of Self-Employed and Small Businesses Ltd., that:

"It would in my view be a grave lacuna in our system of public law if a pressure group, like the federation, or even a single public-spirited

\footnotetext{
${ }^{15}$ Ex parte Blackbum (1976) ibid at p.559 referring to his judgment in McWhirter's Case [1973] Q.B. 629 at 649 . These words were approved by Lord Diplock in $R$. v. Inland Revenue Commissioners ex parte National Federation of Self-Employed and Small Businesses [1982]

A.C. 617 at 644 .

${ }^{16}$ [1978] A.C. 435.

${ }^{17} R$. v. Solicitor General ex parte Taylor [1996] C.O.D. 91.
} 
taxpayer, were prevented by outdated technical rules of locus standi from bring the matter to the attention of the court to vindicate the rule of law and get the unlawful conduct stopped."18

Similarly in $R$. v. Secretary for Foreign and Commonwealth Affairs ex parte World Development Movement Ltd., where a non-partisan pressure group that had campaigned for many years to improve the quality of overseas aid given by the British government to underdeveloped countries was found to have standing to challenge to challenge a decision by Her Majesty's Government to grant aid for the construction of the Pergau Dam in Malaysia. ${ }^{19}$ The court took into account the expertise of the applicant; but was primarily moved by the fact that no one else would be able to bring the challenge if the World Development Movement was excluded. This is, of course, a vindication of the logic of the position that Lord Denning had consistently adopted.

\section{THE INTRODUCTION OF LEGITIMATE EXPECTATIONS}

The concept of legitimate expectation lies at the cutting edge of developments in the law of natural justice. Lord Denning both invented the concept as far as English law is concerned and he gave the name "legitimate expectations" to the similar, but not identical, principle that operates in European Law. It is well known that in Schmidt v. The Home Secretary Lord Denning, without any citation of authority, referred to persons who had been granted leave to enter the U.K. for a certain period of time having a "legitimate expectation" of being able to remain until the end of that period and being entitled to a hearing if they were to be required to leave before the expiry of that time. ${ }^{20}$

When I began to study legitimate expectations in the early 1980 s I soon became aware of the existence of a similar concept in the administrative law of the European Communities and in other European countries. Was this the same concept, or if it was a different concept, did both concepts have a common origin? Was this perhaps an example of the transmigration of ideas from European legal systems into English public law? The judgment in Schmidt gave no guidance so I wrote to Lord Denning and asked him.

An answer came back promptly. Lord Denning wished me and my researches well but roundly scotched my thesis. He had thought up the idea himself and certainly had not derived it from any European concept. ${ }^{21}$ What

\footnotetext{
${ }^{18}$ Supra n.15 in fact reversing the Court of Appeal [1980] Q.B. 407.

${ }^{19}$ [1995] 1 W.L.R. 386

${ }^{20}$ [1969] 2 Ch. 149.

${ }^{21}$ See "The Provenance and Protection of Legitimate Expectations" (1988) 47 C.L.J. 238.
} 
else could be expected from "the greatest living Englishman?" Curiously, the phrase "legitimate expectation" was used after Schmidt in European law to describe the concept in European law. ${ }^{22}$ So not only was Lord Denning responsible for the concept in English law but he is also responsible for the name in European law.

Interesting though this juristic archaeology is, what is its significance for today's law? The concept of legitimate expectation forms a valuable and prominent facet of the general and far-reaching duty to act fairly which Lord Denning has done so much in other cases to develop. The doctrine of legitimate expectation addresses the protection of the trust which citizens have placed in statements or practices of those in authority. Citizens, to whom solemn assurances have been made, who have placed their trust in those promises of officials, should not find when that trust is betrayed that the law can give them no remedy.

The point which I wish to pick up lies in the protection of substantive legitimate expectations. An individual may through a promise of a decision-maker ${ }^{23}$ legitimately expect either that a particular procedure will be adopted in reaching the decision (this is a procedural expectation) or the individual may expect a particular (and favourable) decision (this is a substantive expectation). Now clearly procedural expectations are protected simply by requiring that the promised procedure is followed. But what of substantive expectations?

Although substantive protection has been recognised in several cases, it sits awkwardly with the need not to fetter the decision-maker's discretion. Decision-makers must be free to change their previously announced policies and not be bound to follow them. For these reasons the most recent cases suggest that substantive protection of legitimate expectations will only be possible where the change of policy is shown to be irrational. ${ }^{24}$ There is force in these arguments; but should not the trust which has been placed in the policy or undertaking of the decision-maker be protected in some measure? The point that I wish to make is that Lord Denning had already thought of this. In Schmidt, right at the introduction or invention of the principle, Lord Denning said, speaking of the position of an alien who had been given leave to enter and remain for a certain period:

\footnotetext{
${ }^{22}$ Forsyth, ibid.

${ }^{23}$ Or by that decision-maker's practice in adopting a particular practice or policy.

${ }^{24}$ See $R$. v. Home Secretary ex parte Hargreaves [1997] 1 W.L.R. 906 (change in policy on home leave for prisoners not irrational; challenge by prisoners whose first home leave had been substantially delayed by change of policy failed); $R$. v. Inland Revenue Commissioners ex parte Unilever plc [1996] S.T.C. 681 (decision by revenue to abandon practice followed for 20 years of allowing taxpayer, because of the complexity of its affairs, to make claims for loss relief late irrational and decision quashed). For comment see Forsyth, [1997] P.L. 375 and Bamforth, (1997) 56 C.L.J. 1.
} 
"If his permit is revoked before the time limit expires, he ought...to be given an opportunity of making

representations: for he would have a legitimate expectation of being allowed to stay for the permitted time."25

This is, of course, the recognition that a substantive expectation (of being able to stay for a certain period) may be procedurally protected. This surely is the way in which the protection of the trust placed in the undertakings of the decision-maker may be protected while at the same time preserving the freedom of action of the decision-maker. ${ }^{26}$ And it was an idea sprung fully formed from the fertile brain of Lord Denning.

\section{THE JURISTIC BASIS ON NON-STATUTORY REVIEW}

One of the central conundrums of the theory of modern judicial review lies in the failure of conventional theories - typically the doctrine of ultra vires ${ }^{27}$ - to explain the judicial review of bodies which do not exercise statutory powers. However, although the issue awaits authoritative judicial consideration, a consensus seems to be developing that the juristic basis for such judicial review lies in the idea that there is a common law principle that monopoly powers should be exercised fairly and reasonably. ${ }^{28}$ Thus one finds right from cases such as Faramus v. Film Artists Association Lord Denning (here in the minority) placing reliance upon monopoly as the factor indicating that power is not to be used unreasonably and unfairly. ${ }^{29}$ And in the leading case of Nagle v. Feilden the idea of controlling monopoly power once more plays a leading role. ${ }^{30}$ This case, which was heard in the days before legislation against sexual discrimination, concerned the question whether the Jockey Club could adopt a policy of denying training licences to women. But the Jockey Club enjoyed monopoly control over organised racing in the United Kingdom. No one could train racehorses successfully without a licence from the Club. This meant that the Club had to exercise its powers fairly. Lord Denning now in

\footnotetext{
${ }^{25}$ Supra n. 20 at p. 171.

${ }^{26}$ That such protection is possible and, indeed, appropriate is recognised in many cases. See, for instance, Laws J. in $R$. v. Secretary of State for Transport ex parte Richmond upon Thames L.B.C. [1994] I W.L.R. 74 at $92 \mathrm{G}$.

${ }^{27}$ I should reveal that I consider that the conventional doctrine of ultra vires, properly understood, is able to provide the constitutional basis for the judicial review of statutory discretions. See, "Of Fig Leaves and Fairy Tales: The Ultra Vires Doctrine, the Sovereignty of Parliament and Judicial Review" (1996) 55 C.L.J. 122.

${ }^{28}$ See Craig, Administrative Law (Sweet \& Maxwell, 3rd ed. 1994).

${ }^{29}$ [1963] 2 Q.B. 527; [1964] A.C. 925.

${ }^{30}$ [1966] 2 Q.B. 633.
} 
the majority (and clearly influenced by the monopoly position of the Club) said this:

"If a man applies to join a social club and is black-balled, he has no cause of action .... They [the members] can do as they like....But we are not considering a social club. We are considering an association which exercises a virtual monopoly in an important field of human activity. By refusing or withdrawing a licence the stewards can put a man put a man out of business....The common law of England has for centuries recognised that a man has a right to work in his trade or profession without being unjustly excluded from it. He is not to be shut out from it at the whim of those having the governance of it." ${ }^{31}$

It is but a small step from recognising that there is a common law power to regulate monopolies in regard to property and employment to the regulation of procedural justice when such bodies exercise such powers. Reliance on this common law principle justifies the judicial review of bodies that exercise such powers.

$R$. v. The Panel on Takeover and Mergers ex parte Datafin was the crucial case in recognising that there could be judicial review of bodies which exercised neither statutory not prerogative powers. ${ }^{32}$ There it was held that the Takeover Panel, which lacks any "authority de jure" yet exercised great power in the regulation of takeovers of companies listed on the London Stock Exchange, was, none the less, subject to judicial review. The judgment of Lord Donaldson M.R. contains little principled discussion of the proper constitutional or juristic basis of the jurisdiction that the court was asserting. But that principled basis is surely to be found in Lord Denning's common law principle of the regulation of monopolies. Thus does Lord Denning profoundly influence a development that takes place long after his retirement.

\section{OTHER VIEWS OF LORD DENNING}

Professor Jowell in his leading study of the influence of Lord Denning draws the distinction between an "activist model" and a "restraint model" of the judicial process in administrative law. His prime conclusion is that Lord Denning adopted the "activist model" and "with Lord Reid in particular, succeeded in challenging the ...'restraint model' espoused by other leading and persuasive judges (especially Lord Diplock). The

${ }^{31}$ lbid at p.644.

${ }^{32}$ [1987] Q.B. 815 (C.A.). 
development of an activist administrative law is surely one of Lord Denning's great contributions." 33 Anyone with even a nodding acquaintance with the modern administrative law of England will recognise that this conclusion is amply justified.

But it does not follow that everyone is content with this state of affairs or welcomes an "activist administrative law." Consider the view of Eric Young who in his study of Lord Denning and administrative law concludes that:

"Lord Denning's influence on administrative law has, it is
submitted, been very considerable. He has been a major
force in widening the scope for judicial intervention in
relation to the activities of administrative bodies. As a
result, however, of the increased discretion which the courts
have taken to themselves, it has become more and more
difficult to predict when and how judicial control will be
exercised. Little progress has been made towards a
developed system of administrative law....Arbitrary
exercises of judicial power do not provide an answer to
arbitrary exercises of executive power. Whatever the
inadequacies...of present methods of political control over
administrative bodies, the move, under the influence of
Lord Denning, towards giving the judges an unfettered
discretion to decide when and how to intervene in
administrative action does not represent a satisfactory
solution to the question of how to control the activities of
public authorities."34

Is it the case that Lord Denning prevented the creation of a modern system of administrative law by the inconsistency of his decisions? That he while challenging the arbitrary power of the decision-makers in fact he replaced it with the arbitrary power of the judiciary? This is a fundamental charge to which a clear answer must needs be given. Let me commence the answer to that charge by making two inevitable concessions.

First of all, there are inconsistencies in Lord Denning's decisions. He has not always said the same thing. For instance, to give but one example, on the vital but technical issue of the voidness of unlawful administrative acts he has vacillated; although he eventually reached and stands by the right conclusion. ${ }^{35}$ But is some inconsistency not inevitable in the course of a

\footnotetext{
${ }^{33}$ In his "Administrative Law" in J. L. Jowell and J. P.W.B. McAuslan, supra n.1 at p.209.

${ }^{34}$ Young, supra n.l at p.180.

${ }^{35}$ In Firman v. Ellis [1978] 3 W.L.R. 1 Lord Denning accepted that unlawful administrative
} 
long judicial career? And it is not noteworthy that Lord Denning has been willing to recognise the error of his ways. Not for him the arrogance of judicial infallibility.

Secondly, Lord Denning's moral and political views have sometimes not chimed with the tenor of our own day. Great fun may be had by the critics with cases such as Ward v. Bradford Corporation. ${ }^{36}$ This was the case of the trainee teacher, a woman, who had been found to have a man in her room contrary to the rules of the hall of residence. The procedure whereby she was thereafter expelled from the college reeks of moral outrage rather than procedural propriety. The disciplinary rules were changed retrospectively, there were reasonable grounds to suspect bias by the authorities, etc etc. Lord Denning was firmly on the side of moral outrage. He said:

"Instead of going into lodgings she had this man with her, night after night, in the hall of residence where such a thing was absolutely forbidden. That is a fine example to set to others. And she a girl training to be a teacher! I expect the governors and the staff all thought she was quite an unsuitable person for it. She would never make a teacher. No parent would knowingly entrust their child to her care." ${ }^{37}$

But in explanation rather than defence of such statements it should be taken into account that Lord Denning was born into a different world. Victoria was still on the throne. He was called to the bar in 1923. Surely, it is inevitable, given the vast changes wrought in public attitudes and public morality in the course of the many decades since Lord Denning's moral and political ideas were set, that some of his views should bear an out-of-date air. Many would see this as a strength. The only flaw was to allow those views to overwhelm the case for treating Miss. Ward fairly. But remember that there are more than 2,000 reported cases in which Lord Denning gave judgment; and in only a tiny handful of these would moral and political views be found to overwhelm the sound principles of administrative law.

The fundamental charge remains to be answered: that while challenging the arbitrary power of the decision-makers in fact Lord Denning replaced it with the arbitrary power of the judiciary. The answer to it must be that, while a measure of uncertainty will always exist, there is really no

acts were void not voidable (as he had held in Director of Public Prosecutions v. Head [1959]

A.C. 83.

${ }^{36}$ (1972) 70 L.G.R. 27. For another but less extreme example where Lord Denning's moral views coloured his judgment see Cinnamond v. British Airports Authority [1980] 1 W.L.R. 582.

${ }^{37} \mathrm{Ibid}$ at p.30. 
convincing evidence that Lord Denning, or the judiciary as a whole, has been systematically arbitrary in their decisions in administrative cases. ${ }^{38}$ On the contrary, as the areas specifically chosen for discussion earlier in this paper shows there is frequently a deep inner logic to the developments that Lord Denning has initiated or which he has participated in. Thus the development of the principle that for non-judicial decision-makers all errors of law were jurisdictional is not an arbitrary principle but is founded upon the need for consistency and the rule of law. The extension of the rules of standing too is not arbitrary but is founded upon the rule of law not being undermined by decisions being unchallengeable through no challenger having standing. The protection of legitimate expectations too is a clear extension of the obligation of faimess and not arbitrary. And the provision of a juristic basis for the judicial review of non-statutory bodies is a vital constitutional task precisely in order to ensure that such review is not vulnerable to the charge that it is in breach of the rule of law. One may disagree with the extension of judicial review implied by these developments, but they are not arbitrary.

Moreover, Lord Denning has always accepted the supremacy of Parliament. "The judges," he has said, "loyally obey what Parliament has laid down." 39 Not for him the readiness to abandon our constitutional foundations which other judges frustrated by Parliament's failure to do what they considered necessary or fundamental have sometimes toyed with. Judicial decisions - made by Lord Denning as well as other eminent judges - have sometimes been unexpected, they have sometimes been in error but they have seldom been arbitrary. They have always been justified in reasoned and principled judgments. ${ }^{40}$ One should not confuse disagreement with arbitrariness.

\footnotetext{
${ }^{38}$ Given the complexity of the corpus of law (statute and statutory instrument as well as other forms of regulations) that forms the machinery of government in all its manifestations, a considerable degree of uncertainty is inherent within administrative law.

${ }^{39}$ Speech to Justice reported in The Times 29th June, 1977. And see The Discipline of Law, supra n.6 at pp. 8-9. To like affect see $R$. v. Home Secretary ex parte Hosenball [1997] 1 W.L.R. 766.

${ }^{40} \mathrm{Cf}$. the position in South Africa where judges towards the apartheid years often abandoned principled justification for their pro-executive decisions. See, Forsyth, In Danger for Their Talents (Juta \& Co., 1985) at p. 180.

${ }^{41}$ It is often suggested that because interpretation is for the judges their subservience to Parliamentary intent is fictitious. See "The Approach of Humpty Dumpty" cited in Young, supra $\mathrm{n} .1$ at p.157 from an undated Financial Times. The judges are the master of the interpretation and so are not truly subservient. What such arguments overlook, however, is that Parliament can speak again and speak with greater clarity. Judges may resist legislation they disapprove of, but in the end they will (and must) submit to the democratic will. Thus unless the judges truly are "rebels in ermine" Parliament will always have the last word.
} 


\section{CONCLUSIONS AND A SUMMING UP}

It would be commonplace to remark that Lord Denning's vast influence in the creation of modern English administrative law is a considerable achievement. But we should not lose perspective. It was not the work of Lord Denning alone. There were other giants of the subject whose contribution was just as great. Lord Reid, Lord Diplock, Sir William Wade, Professor de Smith and others - any list is bound to have omissions - made contributions of the same order of magnitude. Perhaps Lord Denning's style is unique. Short sentences. Vivid phrases. But Stanley de Smith's compact style was also unique. He packed more learning into a short phrase than many other authors put into a chapter. And Sir William is just as lucid and his contribution continues undiminished to this day.

Lord Denning's contribution was essentially practical. In the craft of the analysis of the decided cases he had legendary skill which at time extended to legerdemain. ${ }^{42}$ But even more his influence rests on the clarity and vividness of his judgments. He is a great communicator; and sometimes he has communicated better with the public as a whole rather than those above him in the judicial hierarchy. His dislike of jurisprudence is well known. One consequence of this is he never articulated with any degree of abstractness the questions of principle that underlay his judicial decisions. One of the few disappointments of those brilliant books The Due Process of Law and The Discipline of Law as well as the subsequent books is that when the focus shifts from law it falls on literature or history, never on jurisprudence or philosophy. But is this not an impractical academic's cavil: the same comment could be made about most judges.

But these qualifications of Lord Denning's achievement all miss the point. All great men have flaws but they remain great men. We would not all be here today were it not for the fact that there is little doubt that on his two hundredth birthday Lord Denning will be remembered. He will be seen as a vital force in the revification of the public law of these islands. And his judgments will still be read. Rather than nit-pick over this achievement we should simply join with Lord Hailsham in his speech on Lord Denning's retirement when he said:

"We shall miss your passion for justice, your independence and quality of thought, your liberal mind...and your

\footnotetext{
${ }^{42}$ But note his views on precedent in The Discipline of Law, supra n. 6 at p.314: "All that I am against is a too rigid application [of precedent]- a rigidity which insists that a bad precedent must necessarily be followed. I would treat [precedent] as a path through the woods. You must follow it certainly so as to reach your end. But you must not let the path become too overgrown. You must cut off the dead wood and trim off the side branches."
} 